\title{
Geographic information system-based area suitability analysis for seaweed cultivation in South Halmahera Regency
}

\author{
Kesesuaian lahan budidaya rumput laut berdasarkan sistem informasi geografi \\ di Kabupaten Halmahera Selatan
}

\author{
Muslim Hi. Salim ${ }^{1}$, Hengky J. Sinjal ${ }^{2}$, and Ridwan Lasabuda ${ }^{2}$ \\ ${ }^{1}$ Program Studi Magister Ilmu Perairan, Program Pascasarjana Universitas Sam Ratulangi. Jln. Kampus Unsrat Kleak, \\ Manado 95115, Sulawesi Utara, Indonesia. \\ ${ }^{2}$ Fakultas Perikanan dan Ilmu Kelautan, Universitas Sam Ratulangi. Jl. Kampus Unsrat Bahu, Manado 95115. \\ Sulawesi Utara, Indonesia. \\ *E-mail: nyong.salim@gmail.com
}

\begin{abstract}
The purpose of this study was to determine the development of seaweed cultivation area based on Geographic Information System (GIS) in South Halmahera District Joronga Islands. Determination of the coordinates used a GPS (Global Positioning System). Physical parameters, such as current and visibility, used a flow-meter and Secchi disc, respectively, while temperature and dissolved oxygen measurements used a 550A YSI Instrument. Water salinity was measured using refractometer and $\mathrm{pH}$ used litmus paper. Total study area was 4,202.96 ha covering Gonone, Tawabi, and Pula Gala. All data were analyzed and interpolated using the tools of ArcGIS 10.1 to yield a suitability map image. The highly suitable area for seaweed culture (S3) found covered 719.77 ha.
\end{abstract}

Keywords: GIS; seaweed; mariculture; Halmahera.

Abstrak: Tujuan penelitian ini adalah untuk menentukan area pengembangan budidaya rumput laut berdasarkan Sistem Informasi Geografi (SIG) di Kepulauan Joronga Kabupaten Halmahera Selatan. Penentuan koordinat menggunakan GPS (Global Positioning System). Pengukuran parameter kualitas perairan dan pengamatan kondisi keberadaan lokasi. Pengukuran parameter fisika berupa arus dan kecerahan masing-masing menggunakan flow-meter dan sechi disk, sedangkan pengukuran suhu serta oksigen terlarut menggunakan water test YSI Instrumen 550A, adapun pengukuran salinitas menggunakan Refraktometer dan $\mathrm{pH}$ menggunakan kertas Lakmus. Semua data dianalisis selanjutnya diinterpolasi menggunakan tools Arcgis 10.1 menghasilkan gambar peta kesesuaian. Wilayah yang sangat sesuai untuk budidaya rumput laut (S3) adalah 719,77 hektar.

Kata-kata kunci: SIG; rumput laut; budidaya laut; Halmahera.

\section{PENDAHULUAN}

Sebagai negara kepulauan terbesar di dunia, Indonesia memiliki potensi sumber daya kelautan dan perikanan yang sangat besar. Hal ini didasari oleh luas laut sebesar 5,8 juta km2 (Kementerian Kelautan dan Perikanan, 2010); oleh karena itu, maka pengembangan sumber daya kelautan dan perikanan dapat diharapkan menjadi salah satu tumpuan pengembangan kegiatan di masa yang akan datang (Apridar, 2014).

Bidang budidaya, potensi lahan tambak cukup luas, yaitu mencapai 1.224 .076 ha tetapi realisasinya hanya 612.530 ha. Potensi budidaya laut 8.363.501 ha tetapi realisasi hanya 74.543 ha. Tenaga kerja budidaya ikan sebanyak 2.916.000 orang tetapi kepemilikan lahan perkapita rendah dan hidupnya memprihatinkan. Sedangkan di bidang industri pengolahan ikan, tercatat jumlah industri perikanan lebih dari 17.000 buah tetapi sebagian besar masih bersifat tradisional, berskala mikro dan kecil. Jumlah industri pengolahan ikan skala menengah dan besar sebanyak 767 buah tetapi hanya menyerap tenaga kerja 179.333 orang. Industri pengalengan ikan, terdaftar lebih dari 50 perusahaan tetapi yang berproduksi lebih kurang $50 \%$ dengan kapasitas produksi maksimum sekitar 60\% (Info Media, 2013).

Menurut masterplan minapolitan Kabupaten Halmahera Selatan tahun 2012, potensi lahan budidaya rumput laut di kepulauan Joronga mencapai 1000 ha. Program Dinas Kelautan dan Perikanan menunjukkan, bahwa pengembangan budidaya rumput laut di perairan kepulauan ini seluas kurang lebih 16 ha. Keberhasilan budidaya rumput laut tidak terlepas dari baiknya kualitas 
perairan; oleh karena itu, maka penentuan lokasi yang sesuai sangat penting diketahui untuk pelaksanaan kegiatan budidaya rumput laut secara berkelanjutan (DKP, 2008).

Perencanaan pengembangan budidaya rumput laut di Indonesia masih banyak mengalami hambatan; hal yang sama terjadi di Kab. Halmahera Selatan. Salah satu kendalanya adalah lokasi perairan yang kurang cocok bagi kegiatan budidaya laut dan kualitas perairan yang tidak sesuai (Ahmad et al., 1995) dalam (Wisnu, 2007).

Menurut Irfan (2015), budidaya merupakan salah satu kegiatan yang dilakukan di perairan, baik perairan tawar, payau, maupun laut. Kegiatan budidaya memberikan dampak signifikan terhadap lingkungan dan sumber daya alam dan sejumlah aktivitas yang berada dalam lingkungan itu. Keberhasilan budidaya rumput laut tidak terlepas dari baiknya kualitas perairan; oleh karena itu, maka penentuan lokasi yang sesuai sangat penting diketahui untuk pelaksanaan kegiatan budidaya rumput laut secara berkelanjutan.

Berdasarkan hal tersebut di atas, telah dilakukan penelitian yang bertujuan untuk menganalisis kesesuaian lahan budidaya rumput laut berdasarkan sistem informasi geografi di Kab. Halmahera Selatan.

\section{MATERIAL DAN METODA}

Penelitian dilaksanakan pada Bulan Januari - Maret 2015 di Kecamatan Kepulauan Joronga, yaitu di Desa Gonone, Desa Pulo Gala, dan Desa Tawabi, Kab. Halmahera Selatan. Pengumpulan data lapangan dilakukan melalui kegiatan observasi secara langsung. Prosedur pengukuran parameter fisika, kimia, dan biologi perairan dilakukan pada beberapa stasiun pengamatan, baik pada lokasi yang diidentifikasi adanya kegiatan budidaya rumput laut maupun perairan sekitarnya.

Pada setiap lokasi penelitian, ditentukan masing-masing stasiun titik pengukuran parameter kualitas air dengan menggunakan global positioning system (GPS) (Anonim, 2007). Hal ini bertujuan untuk dapat melihat kondisi perairan sesuai kriteria parameter kualitas air setelah diolah dengan program sistem informasi geografis (SIG) pada masing-masing koordinat yang menjadi target pengukuran. Pertimbangan, dalam pemilihan lokasi pengambilan sampel air dari badan air harus diambil dari lokasi yang dapat menggambarkan karakteristik keseluruhan badan air (Effendi, 2000).

Kriteria yang digunakan sebagai acuan dalam pemberian nilai kesesuaian budidaya rumput laut mengacu pada beberapa sumber yang dirangkum dalam Tabel 1.

\section{Analisis Data}

Sesuai metode yang dilakukan dalam penelitian ini maka ada beberapa tahapan dalam menganalisis data meliputi: pembobotan data penelitian, selanjutnya dilakukan pengurutan data berdasarkan parameter pada semua stasiun penelitian dan interpolasi data dengan menggunakan Sistem Informasi Geografis (SIG) untuk menghasil peta kesesuaian berdasarkan parameter perairan. Keseluruhan peta hasil interpolasi kemudian ditumpang lapiskan (Overlay) sehingga menghasilkan peta tematik kesesuaian.

\section{HASIL DAN PEMBAHASAN}

Tabel 1. Kriteria Kesesuaian Lahan Perairan untuk Budidaya Rumput Laut

\begin{tabular}{|c|c|c|c|c|}
\hline No & Parameter & $\begin{array}{l}\text { Sangat sesuai } \\
\text { (S1) }\end{array}$ & $\begin{array}{l}\text { Cukup Sesuai } \\
\text { (S2) }\end{array}$ & $\begin{array}{l}\text { Tidak Sesuai } \\
\text { (S1) }\end{array}$ \\
\hline 1 & Keterlindungan & $\begin{array}{l}\text { Terlindung } \\
\text { (Teluk, Selat) }\end{array}$ & $\begin{array}{l}\text { Agak terlindung } \\
\text { (Perairan Dangkal dengan } \\
\text { Karang penghalang) }\end{array}$ & $\begin{array}{l}\text { Terbuka } \\
\text { (Perairan terbuka) }\end{array}$ \\
\hline 2 & Tinggi Gelombang (m) & $0-0,25$ & $0,26-0,5$ & $>0,5$ \\
\hline 3 & Kecepatan arus $(\mathrm{m} / \mathrm{s})$ & $0,20-0,30$ & $0,10-<0,20:>0,30-\leq 0,40$ & $<0,10:>0,40$ \\
\hline 4 & Kecerahan $(\%)$ & $80-100$ & $60-<80$ & $<60$ \\
\hline 5 & Kedalaman (m) & $2-10$ & $1-<2:>10-\leq 30$ & $<1:>30$ \\
\hline 6 & Substrat Dasar & $\begin{array}{l}\text { Pasir, pecahan karang, } \\
\text { makro alga }\end{array}$ & Pasir berlumpur & Lumpur \\
\hline 7 & Oksigen Terlarut (mg/l) & $\geq 4,0$ & $2,0-<4,0$ & $<2,0$ \\
\hline 8 & Suhu $\left({ }^{0} \mathrm{C}\right)$ & $28-30$ & $25-<28:>30-\leq 33$ & $<25:>33$ \\
\hline 9 & Salinitas (ppm) & $28-34$ & $25-<28:>34-\leq 35$ & $<25:>33$ \\
\hline 10 & $\mathrm{pH}(\mathrm{ppt})$ & $7,0-8,5$ & $6,5-<7,0$ & $<6,5:>8,5$ \\
\hline
\end{tabular}


Salim et al.: Geographic information System-based area suitability analysis for seaweed...

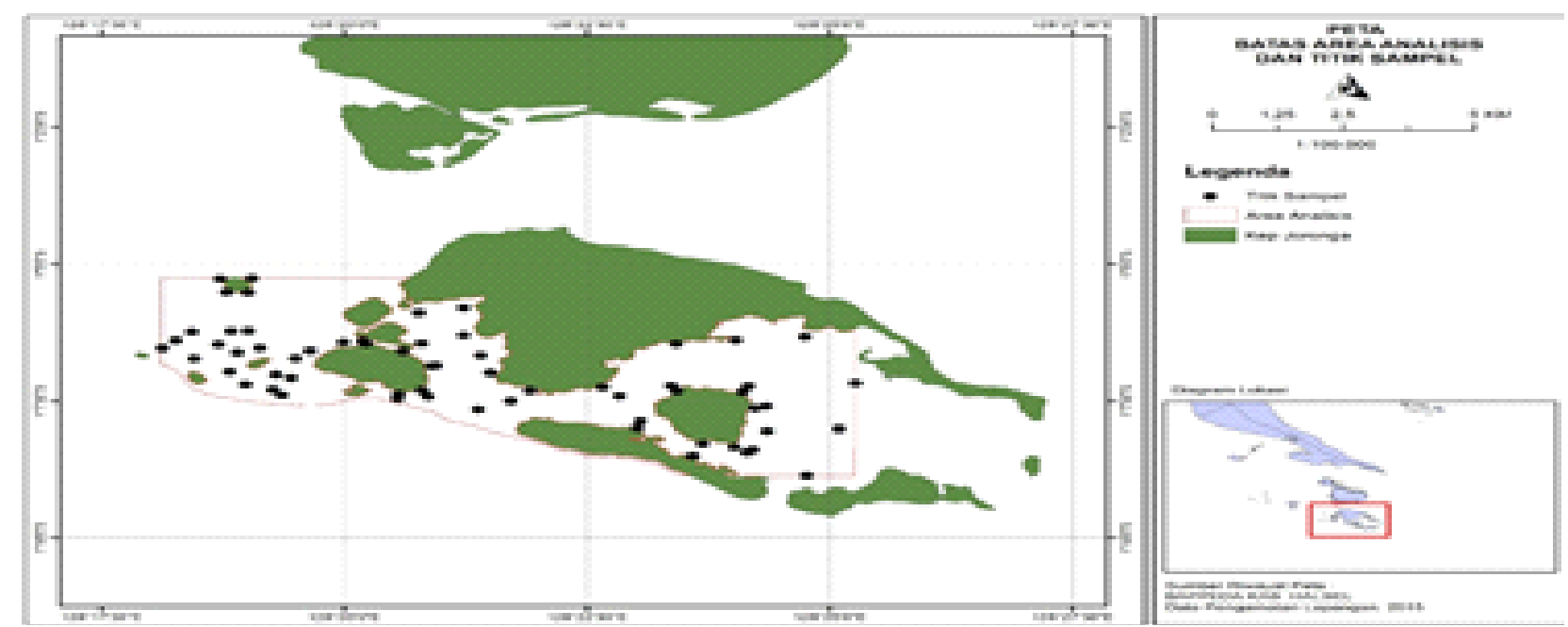

Gambar 1. Peta Titik Pengamatan

Tabel 2. Hasil Pengamatan Kualitas Periran

\begin{tabular}{lc}
\hline Parameter & Hasil Pengamatan \\
\hline Keterlindungan & Terlindung, Agak tertlindung danTerbuka, \\
Substrat Dasar & Karang berpasir, Pasir, lamun dan berlumpur \\
Kedalaman (m) & $0,5-20$ \\
Gelombang (m) & $0,5-0,25$ \\
Arus $(\mathrm{cm} /$ det $)$ & $0,1-0,5$ \\
Kecerahan $>15 \mathrm{~m} \mathrm{( \% )}$ & $75-100$ \\
Oksigen Terlarut (mg/l) & $2,95-7,01$ \\
Suhu $\left({ }^{0} \mathrm{C}\right)$ & $29,2-32,4$ \\
Salinitas $(\mathrm{ppm})$ & $32-35$ \\
pH $(\mathrm{ppt})$ & $6-7$ \\
\hline
\end{tabular}

Secara geografis, area penelitian di desa Gonone berada pada koordinat $01^{0} 05^{\prime} 15.6^{\prime \prime}$ - $01^{0} 07^{\prime} 17.3$ " LS dan $128^{\circ} 18^{\prime} 07.4^{\prime \prime}-128^{\circ} 19^{\prime} 18.0^{\prime \prime}$ BT, meliputi Pulau Gonone, Doro Obi Kecil, Doro Obi Besar, dan Pulau Bangko. Sedangkan area penelitian di Desa Pulo Gala berada pada koordinat $01^{0} 05^{\prime} 47.5^{\prime \prime}$ - 0107'27.0" LS dan 128 19'21.6" - 128021'30.2" BT, meliputi Pulau Bangko, Pulau Tikolo, Pulau Gomutu, Pulau Gala, Pulau Doro Gane, dan Pulau Joronga. Area penelitian Desa Tawabi meliputi Pulau Joronga, Pulau Orang Kaya, Pulau Tawabi, Pulau Jere dan Pulau Tabihahu dengan koordinat 0106'19.2" - 0107'59.8'LS dan 128021'23.1" $128^{0} 25^{\prime} 16.1$ 'BT. Untuk keseluruhan lokasi penelitian, yang menjadi area analisis, berada pada koordinat $01^{0} 05$ ' $15.6 "$ - $01^{0} 07^{\prime} 59.8^{\prime \prime}$ LS dan $128^{0} 18^{\prime} 07.4^{\prime \prime}-128^{0} 25^{\prime} 16.1$ " BT. Area analisis dan titik pengamatan penelitian disajikan pada Gambar 1.

\section{Kesesuaian Lahan Beradasarkan Kualitas Perairan}

Kesesuaian lahan budidaya adalah merupakan kriteria yang mewakili berbagai kesesuaian parameter kualitas perairan pada lokasi penelitian, yang selanjutnya dijadikan sebagai area analisis, (Ratnasari, 2014). Hasil pengukuran parameter fisika dan kima serta pengamatan kondisi biologi dan lingkungan perairan, secara garis besar, dicantumkan dalam Tabel 2, yang meliputi tiga lokasi penelitian, yaitu di Desa Gonone, Pulo Gala dan Tawabi.

Hasil pengamatan menunjukkan, bahwa kesesuaian keterlindungan area penelitian memiliki karakteristik berbeda antara Lokasi Desa Gonone, Pulo Gala, dan Tawabi. Dari ke tujuh belas poin pengambilan sampel pada Desa Gonone, seluruhnya $(100 \%)$ merupakan kategori daerah terlindung karena lokasi berada dan dikelilingi oleh gugusan terumbu karang. Poin pengambilan sampel di Desa Pulo Gala berjumlah 20 titik, untuk area yang 
masuk kategori kesesuaian keterlindungan terbagi atas tiga, yaitu daerah kategori terlindung terdapat pada 7 titik pengamatan, daerah agak terlindung berada pada 10 titik pengamatan, dan daerah kategori terbuka terdapat pada 3 titik pengamatan.

Pengamatan kesesuaian lahan yang dilakukan di Desa Tawabi ditetapkan 25 point dengan kriteria lokasi terlindung sebanyak 15 point, agak terlindung berada pada 7 poin pengamatan, dan 3 point pengamatan adalah kategori perairan terbuka. Adipu (2013) menjelaskan, bahwa daerah keterlindungan pada perairan laut adalah sejauh mana lokasi dapat dipengaruhi oleh angin dan gelombang yang besar sehingga merupakan parameter utama dalam penentuan lokasi. Hasil pengamatan menunjukkan, bahwa pada ketiga lokasi penelitian berada pada daerah terlindung dan sangat sesuai.
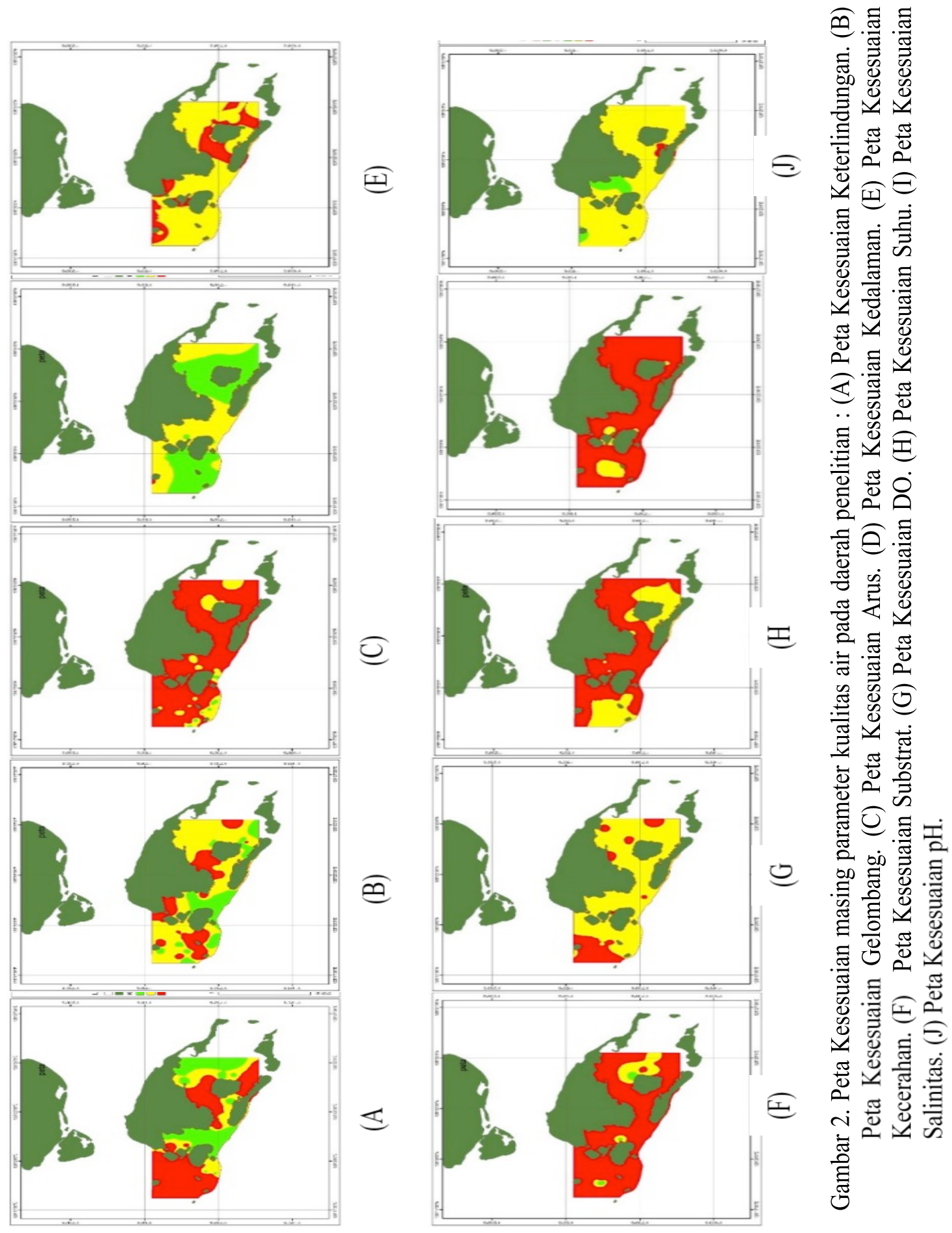
Kondisi perairan lokasi penelitian bergelombang $5 \mathrm{~cm}-20 \mathrm{~cm}$; hal ini sangat menunjang kegiatan budidaya rumput laut. Gelombang yang dikehendaki pada kegiatan budidaya adalah lebih kecil dari $0,5 \mathrm{~m}$ sehingga tidak merusak wadah budidaya (Balitbang SDL P3O LIPI, 1995) dalam (Wisnu $d k k ., 2007$ ).

Hasil pengukuran kecepatan Arus pada lokasi penelitian berkisar $10-40 \mathrm{~cm} /$ det; sesuai dengan penjelasan Mubarak (1982) dalam Wisnu (2007), bahwa kecepatan arus untuk kegiatan budidaya rumput laut adalah $20-40 \mathrm{~cm} /$ detik agar tanaman dapat dibersihkan dari kotoran dan suplai nutrien dapat berjalan dengan baik.

Kedalaman perairan di lokasi budidaya rumput laut pada tiga lokasi penelitian adalah $0,5 \mathrm{~m}$ sampai $>20 \mathrm{~m}$. Hal ini memungkinkan untuk dikembangkan sistem budidaya dengan metode berbeda pada lokasi yang memiliki kedalam lebih dari 3 meter.

Nilai kecerahan lokasi penelitian mencapai $100 \%$ pada kedalaman hingga 12 meter. Substrat dasar daerah penelitian ditemukan adanya perbedaan di mana pada Desa Gonone yang mendominasi adalah subtrat karang berpasir, Desa Pulogala adalah substrat pasir dengan lamun, dan di Desa Tawabi ditemukan pasir dengan lamun dan sebagian berlumpur pada substrat perairan.

Menurut Deptan (1998) dalam Wisnu (2007), bahwa oksigen terlarut dibutuhkan bagi keberlangsungan hidup rumput laut dengan nilai $3-8 \mathrm{mg} / \mathrm{l}$. Hal ini sesuai dengan data pengukuran pada lokasi penelitian di mana kandungan oksigen berada pada $3,10-5,13 \mathrm{mg} / \mathrm{l}$.

Suhu perairan untuk budidaya rumput laut, menurut Mubarak et all., (1995) dalam Affan
(2012), adalah dengan kisaran $20-30{ }^{0} \mathrm{C}$. Hasil pengukuran parameter suhu pada lokasi penelitian, ditemukan pada kisaran $24-30,7{ }^{\circ} \mathrm{C}$; derajat ini masih dapat dikatakan layak untuk dijadikan sebagai lokasi budidaya.

Hasil pengukuran salinitas pada ketiga lokasi penelitian, didapatkan nilai dengan kisaran 32 - 35 ppt. Hal ini sedikit berbeda dengan penjelasan menurut Sadhori (1989) dan Ambas (2006) dalam Adipu (2013), bahwa salinitas yang cocok untuk pertumbuhan rumput laut adalah dengan kisaran 31 - 35 ppt dan 28 - 34 ppt.

Menurut Marasabessy dkk. (2010), salinitas di perairan Pulau Bacan berkisar 33,742 - 34,332 ppt dengan rerata sebesar 34,195 ppt. Salinitas di perairan ini masih sesuai dengan salinitas yang dijumpai di perairan laut umumnya; salinitas di perairan Indonesia, umumnya, berkisar antara 30,0 35,0 ppt. Untuk daerah pesisir, salinitas berkisar 32,0 - 34,0 ppt; sedangkan untuk laut terbuka, umumnya, salinitas berkisar 33,0 - 37,0 ppt dengan rata-rata $35,0 \mathrm{ppt}$.

Nilai $\mathrm{pH}$ lokasi penelitian berkisar $6-8$; rumput laut tumbuh pada $\mathrm{pH}$ berkisar 6 - 9; sedangkan untuk bertumbuh dengan baik, rumput laut membutuhkan $\mathrm{pH}$ pada kisaran 7 - 8,5 (Departemen Pertanian, 1998; Aslan, 1998 dalam Wisnu, 2007). Duma (2012) menyatakan, bahwa lokasi yang baik untuk pertumbuhan rumput laut sebaiknya memiliki kisaran $\mathrm{pH}$ 7,2 - 7,6. Sedangkan Poncomulyo $d k k$. (2006) menyatakan, bahwa lokasi yang di pilih untuk budidaya rumput laut sebaiknya memiliki pH berkisar 7,3 - 8,2. Kondisi $\mathrm{pH}$ di lokasi penelitian menunjukkan masih layak dijadikan tempat budidaya rumput laut.

Semua data yang telah diolah selanjutnya

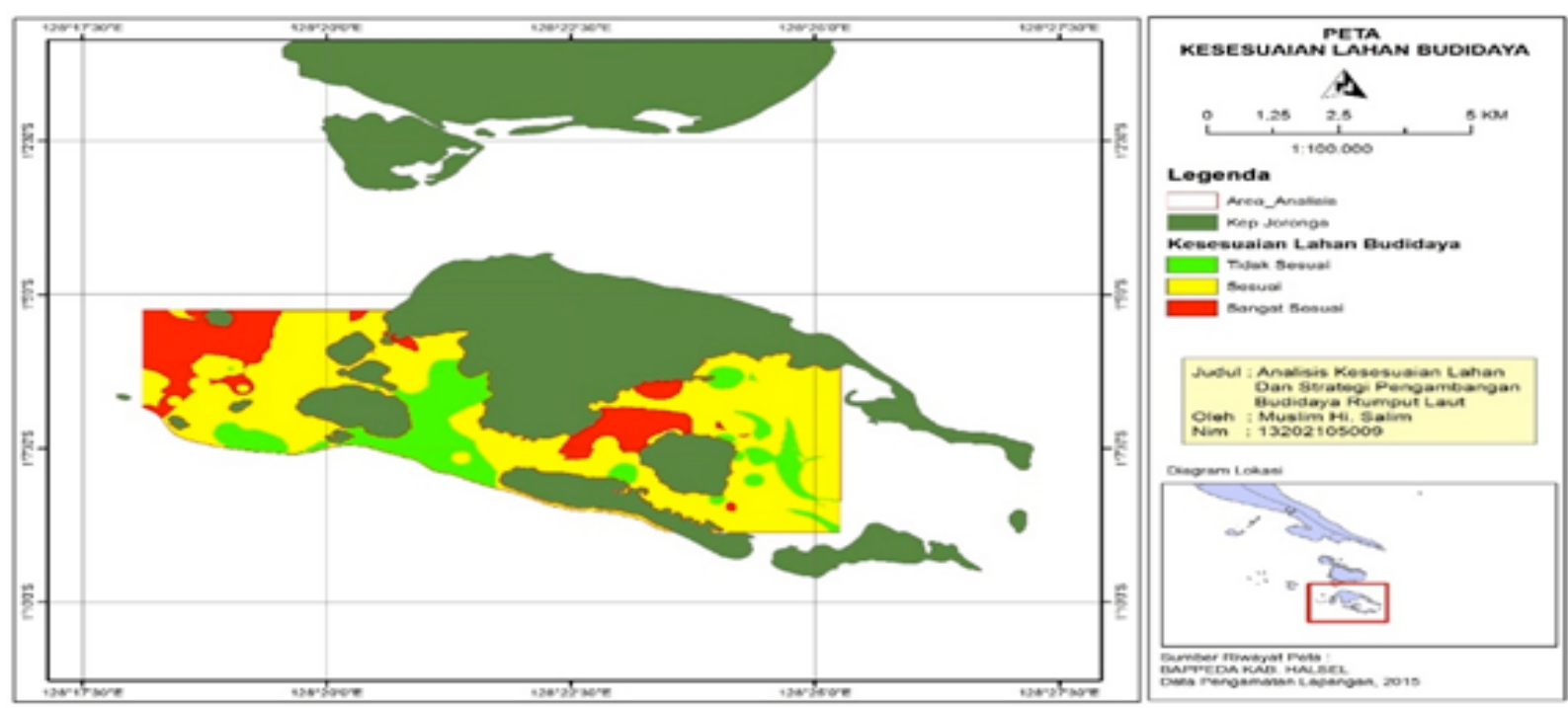

Gambar 3. Peta kesesuaian lahan dan strategi pengembangan budidaya rumput laut di Kabupaten Halmahera Selatan 
diinterpolasi dengan menggunakan tools ARCGIS 10.1 sehingga menghasilkan gambar peta kesesuaian berdasarkan masing-masing parameter seperti pada Gambar 2.

Peta kesesuaian lahan budidaya adalah merupakan hasil dari proses tumpang susun (overlay) antara beberapa layer peta kesesuaian parameter sehingga menghasilkan gambar peta kesesuaian lahan budidaya seperti pada layout peta pada Gambar 3.

Berdasarkan layout peta hasil kesesuaian lahan, selanjutnya dilakukan kalkulasi area pada tools Arcgis 10.1, yang menghasilkan nilai dengan masing-masing kelompok Gridcode. Berdasarkan peta kesesuaian lahan budidaya yang dihasilkan (Gambar 3), terhitung luas lahan budidaya yang sesuai kriteria kesesuaian, terbagi menjadi tiga kelompok.

Nilai penjumlahan luas total area analisis berdasarkan Gridcode dari peta kesesuaian lahan budidaya adalah seluas 4202,96 ha yang meliputi wilayah Desa Gonone, Desa Tawabi, dan Desa Pulo Gala. Adapun luas perairan dari masing-masing nilai kesesuaian tersebut terbagi dalam 3 kelompok Gridcode, yaitu:

1. Kesesuaian lahan untuk Gridcode 1 atau "Tidak Sesuai" (S1), seluas 778,15 ha lahan perairan yang terdapat pada lokasi penelitian.

2. Jumlah total luas kesesuaian lahan untuk Gridcode 2 atau "Sesuai" (S2) adalah area yang mendominasi, seluas 2705,03 ha, yang dapat dijadikan sebagai lahan untuk kegiatan budidaya perikanan.

3. Luas kesesuaian lahan untuk Gridcode 3 atau "Sangat Sesuai" (S3) adalah perairan yang dapat dijadikan sebagai lahan untuk pengembangan budidaya rumput laut, seluas 719,77 hektar.

\section{KESIMPULAN}

Dalam wilayah perairan Kab. Halmahera Selatan, yang seluas $31.484,40 \mathrm{~km}^{2}$ atau sekitar $78 \%$ dari luas total Kabupaten tersebut, terdapat potensi lahan budidaya perikanan seluas 30.050 ha. Wilayah pengembangan budidaya rumput laut di Kepulauan Joronga, Kab. Halmahera Selatan, seluas 719,77 ha dengan kategori "Sangat Sesuai" (S3), dengan kategori "Sesuai" (S2) seluas 2705,03 ha, dan 778,15 ha berkategori "Tidak Sesuai" (S1).

\section{REFERENSI}

ADIPU, Y. (2013) Kesesuaian lahan Budidaya Laut Diperairan Kabupaten Bolomongondow Selatan Sulawesi Utara. Manado: Universitas Sam Ratulangi.

AFFAN, J.M. (2012) Identifikasi Lokasi Keramba Jaring Apung (KJA) Berdasarkan Faktor Lingkungan Dan Kualitas Air Di Perairan Pantai Timur Bangka Tengah. Banda Aceh: Departemen Perikanan Universitas Syiah Kumala

ANONIM (2007) Modul Pelatihan ArcGis Tingkat Dasar. Banda Aceh: GIS Konsorsium Aceh Nias.

APRIDAR (2014) Daya Saing Ekspor Ikan Tuna Indonesi. Yogyakarta: Graha Ilmu.

BAPPEDA (2012) Laporan Akhir Masterplan Pengembangan Kawasan Minapolitan. Kabupaten Halmahera Selatan.

DKP. (2008) Profil Dinas Kelautan dan Perikanan. Kabupaten Halmahera Selatan.

EFFENDI, H. (2000) Telaah Kualitas Air Bagi Pengelolaan Sumberdaya dan Lingkungan Perairan. Bogor: Institut Pertanian Bogor.

INFO MEDIA (2013) Kementeraian Kelautan Perikanan Soroti Pengembangan Budidaya Laut. Tribunnews.com. Jakarta Tanggal 03 Desember 2013, hal. 2

IRFAN, M. (2015). Bioekologi Budidaya Laut Dan Cara Budidaya. Lembaga Penerbit Universitas Khairun, Ternate.

MARASABESSY, dkk. (2010) Pemantauan Kadar Logam Berat Dalam Air Laut Dan Sedimen Di Perairan Pulau Bacan, Maluku Utara. Makara Sains, 14(1): 32-38.

RATNASARI, A. (2014) Pemanfaatan Data Penginderaan Jauh Dan Sistem Informasi Geografis Untuk Penentuan Lokasi Budidaya Rumput Laut Di Perairan Teluk Gerupuk, Pulau Lombok, Provinsi Nusa Tenggara Barat. Bogor: Departemen Budidaya Perairan, Fakultas Perikanan Dan Ilmu Kelautan, Institut Pertanian Bogor.

WISNU A.R. dkk. (2007) Analisis kesesuain Perairan Pulau Karimun Jawa dan Pulau Kemujan Sebagai Lahan Budidaya Rumput Laut Menggunakan Sistem Informasi Geografis. Jurnal Pasir Laut, 3: 27-45.

Received: 15 May 2017 Accepted: 20 July 2017 